\title{
Clinicopathological significance of carbonic anhydrase 9, glucose transporter-1, Ki-67 and p53 expression in oral squamous cell carcinoma
}

\author{
YUHEI KONDO $^{1}$, KAZUHIRO YOSHIKAWA $^{2}$, YUKINOBU OMURA ${ }^{1}$, ATSUSHI SHINOHARA $^{1}$, \\ YOSHIAKI KAZAOKA ${ }^{1}$, JUNJI SANO ${ }^{3}$, YOSHIMI MIZUNO ${ }^{3}$, TOYOHARU YOKOI ${ }^{3}$ and SHIRO YAMADA $^{1}$ \\ Departments of ${ }^{1}$ Oral and Maxillofacial Surgery, ${ }^{2}$ Division of Clinical Research Promotion, Aichi Medical University \\ School of Medicine, and ${ }^{3}$ Division of Pathology, Aichi Medical University Hospital, Nagakute, Aichi 480-1195, Japan
}

Received December 16, 2010; Accepted January 19, 2011

DOI: 10.3892/or.2011.1216

\begin{abstract}
Carbonic anhydrase 9 (CA9) is a glycoprotein present on the surface of cell membranes. It is expressed in $90 \%$ of renal cancer cells, but not in normal kidney tissue. Immunotherapy targeting CA9 is underway, and our group has also conducted a clinical trial using CA9 as a cancer vaccine and confirmed the induction of cytotoxic T lymphocytes, with efficacy in some cases. Expression of CA9 antigen in oral cancer has not been reported in Japan, but our results indicate that immunotherapy targeting CA9 might be possible. We immunohistochemically observed the expression of antigens such as CA9, Ki-67, glucose transporter-1 (GLUT-1) and p53 in 107 subjects with oral squamous cell carcinoma, and examined their correlation with clinicopathological parameters. Immunostaining analysis showed expression of CA9 in $98 \%$ of oral cancer subjects, and the survival rate was significantly lower in subjects with CA9 antigen expression in $50 \%$ or more cells $(\mathrm{P}<0.05)$. Subjects with poorly differentiated, T4 and lymph node metastasis, or Stage IV cancer with high CA9 expression ( $\geq 50 \%$ ) had a worse outcome than those with low CA9 expression. Although GLUT-1 expression was observed in $98 \%$ of subjects, similarly to CA9 expression, no significant correlation between its expression and the survival rate was seen. However, subjects with lymph node metastasis had significantly higher GLUT-1 expression, demonstrating that GLUT-1 could be an indicator of lymph node metastasis. Ki-67 was expressed in $92 \%$ of subjects, but no correlation with outcome was observed. Expression of p53 was noted in $78 \%$ of subjects, and it was found that many oral cancers have p53 genetic abnormalities, but no correlation between
\end{abstract}

Correspondence to: Dr Kazuhiro Yoshikawa, Division of Clinical Research Promotion, Aichi Medical University, Nagakute, Aichi 480-1195, Japan

E-mail: yoshikaw@aichi-med-u.ac.jp

Key words: carbonic anhydrase 9, glucose transporter-1, Ki-67, p53, oral squamous cell carcinoma p53 and outcome was observed. It was confirmed that CA9 antigen is expressed in most oral cancer subjects, suggesting the possibility of immunotherapy targeting CA9 antigen in oral cancer.

\section{Introduction}

Among annual deaths of Japanese in 2009, $>340,000$ deaths were from malignant neoplasms (cancers), of which 6500 deaths $(2 \%)$ were from oral malignant neoplasms. Many oral malignant neoplasms (oral cancer) are squamous cell carcinoma, and most of them develop in the tongue, with slightly higher frequency in men than in women (1). Approximately $50 \%$ of patients have cervical lymph node metastasis at the time of diagnosis, and the outcome of these patients is poor (2-4). In addition, the 5-year disease-free survival rate of patients with oral cancer decreases from $75 \%$ in Stage I to $22 \%$ in Stage IV (5), indicating that it is important to find markers for early detection of cancers and to develop more effective treatments.

Carbonic anhydrase 9 (CA9) is a glycoprotein present on the surface of cell membranes. It is absent in normal renal tissue, but is expressed in $90 \%$ of renal cell carcinomas (6). This is a cancer-associated antigen recognized by antibodies, produced by cervical cancer or renal cell carcinoma cells, and is expressed in normal tissues of gastrointestinal tract membranes, bile ducts (7) and skin (unpublished data). Recently, many research groups have reported its expression not only in renal cell carcinoma and cervical cancer, but also in bladder cancer, non-small cell lung cancer, breast cancer, head and neck cancer, esophageal cancer, stomach cancer, large intestine cancer, bile duct cancer, sarcoma and chronic myeloid leukemia (8-18). Yoshikawa et al prepared mousederived renal cell carcinoma cells expressing human CA9 antigen. They induced cytotoxic T lymphocytes (CTLs) using $\mathrm{Balb} / \mathrm{c}$ mice with the same anchor motif as human HLA-A24, and identified an amino acid sequence of CA9 antigen-derived peptide that is recognized by CTL. Based on the results, they also conducted a clinical study using CA9 antigen-derived peptide as a cancer vaccine, and confirmed the safety of the peptide treatment and the induction potential of CTL (19). 
Currently, the principal treatments for oral cancer are surgery, chemotherapy and radiation therapy. However, it is anticipated that immunotherapy will bring about good results. If the expression of CA9 antigen can be confirmed in oral cancer patients, especially in those with a poor prognosis, immunotherapy targeting CA9 will be possible; however, there have been no studies conducted in Japan on the expression of CA9 antigen in oral cancer in Japanese patients.

In this study, we immunohistochemically examined 107 patients with oral squamous cell carcinoma, confirmed the expression of antigens including CA9, and discussed the correlation with clinicopathological parameters.

\section{Materials and methods}

Patients. We conducted a study in 107 patients who attended the Department of Dentistry and Oral Surgery, Aichi Medical University Hospital between April 1992 and March 2009 and were diagnosed with squamous cell carcinoma according to UICC classification (20), underwent surgical removal of the tumor, and completed post-surgery treatment. Our protocol of this study was reviewed and approved by the institutional review board of Aichi Medical University School of Medicine. The subjects were followed up for a maximum of 60 months after primary tumor removal, and age and gender, tumor site, degree of histopathological differentiation, $\mathrm{T}$ classification, $\mathrm{N}$ classification and disease stage were used for clinicopathological analysis.

Immunohistochemical staining. Based on the normal method of histopathological examination, samples were fixed with formalin solution, embedded in paraffin, and $4-\mu \mathrm{m}$ paraffin sections were prepared. After deparaffination, antigen was activated with microwave, endogenous peroxidase was inactivated, attachment of non-specific protein was blocked, and rabbit anti-CA9 antibody (1:500, ab15086, Abcam, Cambridge, UK), rabbit monoclonal anti-Ki-67 antibody (1:100, clone: SP6, Abcam), mouse monoclonal anti-GLUT-1 antibody (1:200, clone: SPM498, Thermo, Rockford, IL, USA), and mouse monoclonal anti-human p53 antibody (1:50, clone: DO-7, Dako, Glostrup, Denmark) were reacted as primary antibodies overnight at $4{ }^{\circ} \mathrm{C}$. As secondary antibodies, horse anti-rabbit Ig (ImmPRESS ${ }^{\mathrm{TM}}$ Reagent, Vector Laboratories, Inc., CA, USA) was reacted with CA9 and Ki-67, and horse anti-mouse Ig (ImmPRESS Reagent, Vector Laboratories, Inc.) was reacted with GLUT-1 and p53 for $1 \mathrm{~h}$ at room temperature. Subsequently, they were developed with 3,3'-diaminobenzadine (DAB) (Wako Pure Chemical Industries, Ltd., Osaka, Japan), and counterstained with hematoxylin, dehydrated and encapsulated for microscopic examination. As a negative control, normal rabbit serum or normal mouse serum was used instead of primary antibodies. Observation was made with an Axioplan2 and Axiophot2 Universal Microscope (Carl Zeiss Co., Ltd., Jena, Germany), and digital images were obtained with an Axio Vision 4.5 (Carl Zeiss Co., Ltd.). In order to calculate the antigen prevalence, Image J software was used. Cancers with a positive rate of cells of $10 \%$ or more were considered positive, while those with a positive rate of $<10 \%$ were considered negative.
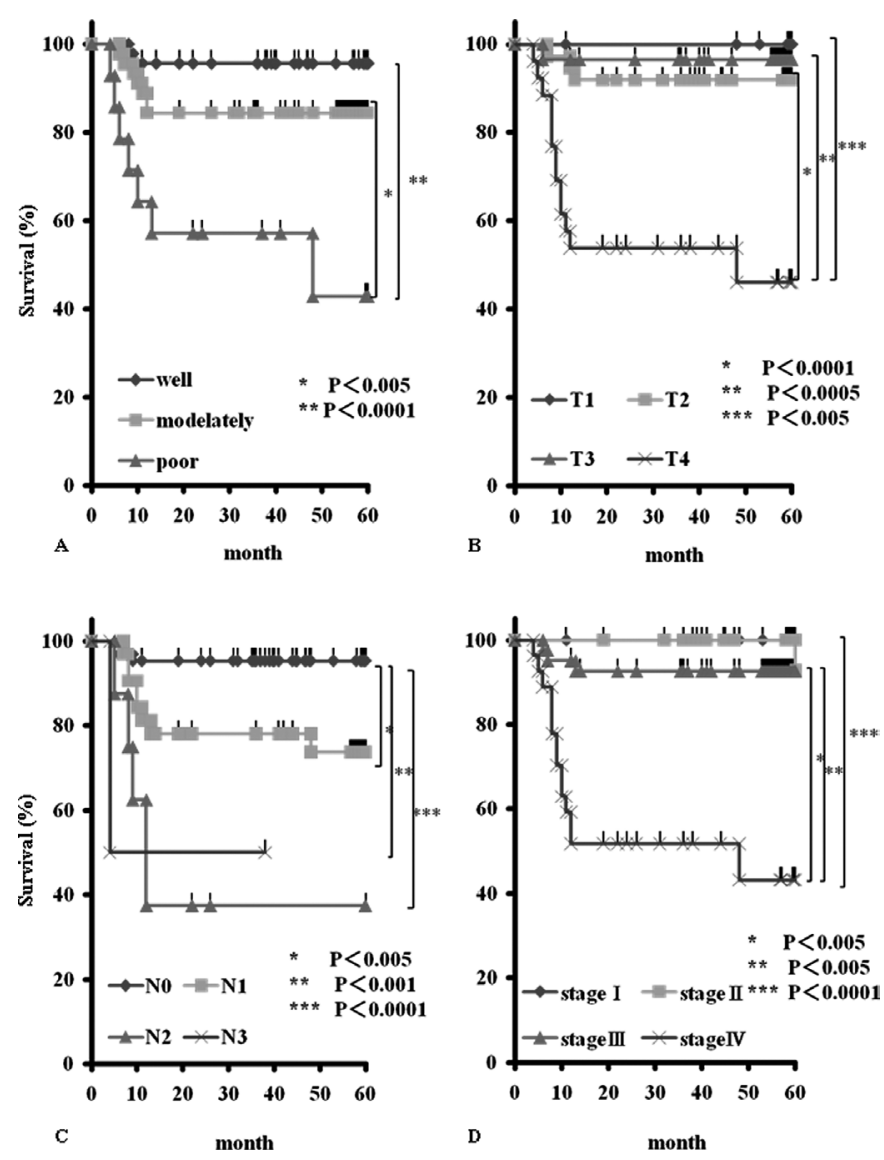

Figure 1. Clinicopathological survival analysis. The results indicate that subjects with poorly differentiated, T4, lymph node metastatic or Stage IV cancer had a poor outcome. (A) Tumor differentiation, (B) Stage, (C) T classification, (D) $\mathrm{N}$ classification.

Statistical analysis. StatView (ver. 5.0, SAS Institute Inc., NC, USA) was used for statistical analysis. For Kaplan-Meier survival analysis, log-rank test of the clinical samples was used. Chi-squared test was used for between-group comparisons. $\mathrm{P}<0.05$ was considered statistically significant.

\section{Results}

Clinicopathological parameters and survival rates. Table I shows the characteristics of the subjects. In this study, 107 subjects (61 male and 46 female) with mean age of 63 (range: 20-93) years participated. The most common site of the primary tumor was the tongue in 52 subjects, followed by gingiva (43 subjects), floor of mouth (5 subjects), pharynx (3 subjects), lips (3 subjects) and buccal mucosa (1 subject).

According to the degree of histological differentiation, 48 subjects had carcinomas of well-differentiated type, 45 had moderately-differentiated type and 14 had poorly-differentiated type. According to T classification, 16 subjects had T1, 37 had T2, 28 had T3, and 26 had T4 carcinomas. According to $\mathrm{N}$ classification, 65 subjects had N0, 32 had N1, 8 had N3, and 2 had N3 carcinomas. No subject had distant metastasis. According to the disease stage classification, 14 subjects were Stage I, 25 Stage II, 41 Stage III and 27 Stage IV.

We examined the correlation between these clinicopathological parameters and the survival rate, and found that 
Table I. Characteristics of patients.

\begin{tabular}{|c|c|}
\hline Characteristics & Number of patients (\%) \\
\hline \multicolumn{2}{|l|}{ Gender } \\
\hline Male & $61(57)$ \\
\hline Female & $46(43)$ \\
\hline Age & $63(20-93)$ \\
\hline \multicolumn{2}{|l|}{ Anatomic site } \\
\hline Tongue & $52(48)$ \\
\hline Gingiva & $43(40)$ \\
\hline Oral floor & $5(5)$ \\
\hline Pharynx & $3(3)$ \\
\hline Lip & $3(3)$ \\
\hline Buccal & $1(1)$ \\
\hline \multicolumn{2}{|c|}{ Degree of differentiation } \\
\hline Well & $48(45)$ \\
\hline Moderately & $45(42)$ \\
\hline Poor & $14(13)$ \\
\hline \multicolumn{2}{|l|}{$\mathrm{T}$ classification ${ }^{\mathrm{a}}$} \\
\hline $\mathrm{T} 1$ & $16(15)$ \\
\hline $\mathrm{T} 2$ & $37(35)$ \\
\hline $\mathrm{T} 3$ & $28(26)$ \\
\hline $\mathrm{T} 4$ & $26(24)$ \\
\hline \multicolumn{2}{|l|}{$\mathrm{N}$ classification ${ }^{\mathrm{b}}$} \\
\hline No & $65(61)$ \\
\hline $\mathrm{N}(1+2+3)$ & $42(39)$ \\
\hline $\mathrm{N} 1$ & $32(30)$ \\
\hline $\mathrm{N} 2$ & $8(7)$ \\
\hline N3 & $2(2)$ \\
\hline \multicolumn{2}{|l|}{ Stage } \\
\hline $\mathrm{I}$ & $14(13)$ \\
\hline II & $25(23)$ \\
\hline III & $41(39)$ \\
\hline IV & $27(25)$ \\
\hline
\end{tabular}

${ }^{\mathrm{a}} \mathrm{T}$, tumor; ${ }^{\mathrm{b}} \mathrm{N}$, lymph node.

subjects with poorly-differentiated type carcinoma had a significantly worse outcome than those with well- $(\mathrm{P}<0.0001)$ or moderately- $(\mathrm{P}<0.005)$ differentiated type (Fig. 1A). Subjects with T4 carcinoma had a poorer outcome than those with $\mathrm{T} 1(\mathrm{P}<0.005), \mathrm{T} 2(\mathrm{P}<0.0001)$ or $\mathrm{T} 3(\mathrm{P}<0.0005)$ carcinomas (Fig. 1B). A significant difference was observed between subjects with N0 and those with $\mathrm{N} 1(\mathrm{P}<0.005), \mathrm{N} 2$ $(\mathrm{P}<0.0001)$ or $\mathrm{N} 3(\mathrm{P}<0.001)$ (Fig. $1 \mathrm{C})$. Outcome was poor in subjects with lymph node metastasis. Outcome was significantly different among disease stages; Stage IV subjects had a significantly poorer outcome than Stage I $(\mathrm{P}<0.0001)$, Stage II $(\mathrm{P}<0.005)$ or Stage III $(\mathrm{P}<0.005)$ subjects $($ Fig. $1 \mathrm{D})$.

Expression of antigens in oral cancer. CA9 was stained positive in cancer cell membranes and a part of the cytoplasm, and
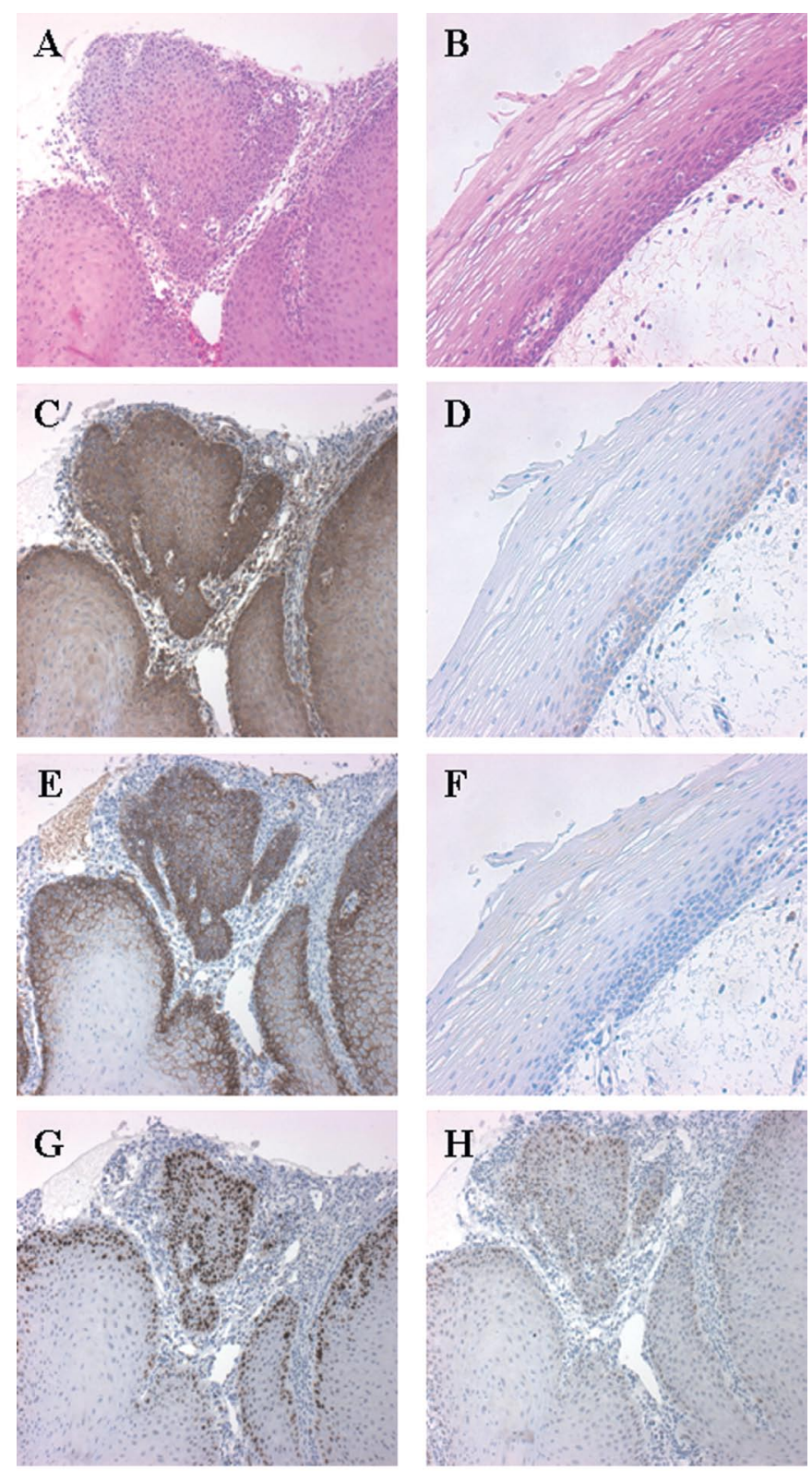

Figure 2. Immunohistochemical staining of CA9, GLUT-1, Ki-67 and p53 in oral squamous cell carcinoma and normal epithelial tissue (magnification, $\mathrm{x} 20$ ). (A) Hematoxylin-eosin staining of oral squamous cell carcinoma. (B) Hematoxylin-eosin staining of normal epithelial tissue. (C) CA9 expression; brown colored cytoplasmic and membranous staining. (D) In normal epithelial tissue, CA9 was stained slightly positive in the basal part of the mucosal epithelium. (E) GLUT-1 expression; brown colored membranous staining. (F) In normal epithelial tissue, GLUT-1 was not stained. (G) Ki-67 expression; brown colored nuclear staining. (H) p53 expression; brown colored nuclear staining.

GLUT-1 was stained positive in cancer cell membranes. In normal epithelial tissue, CA9 was stained slightly positive in the basal part of the mucosal epithelium. In most subjects, both Ki-67 and p53 were stained strongly positive in cancer cell nuclei (Fig. 2). Antigen prevalence and mean positive rate were 98 and 39\%, respectively for CA9 antigen (Table II), 98 and $37 \%$ for GLUT-1 antigen, 92 and 34\% for Ki-67 antigen, and 78 and $34 \%$ for p53 antigen.

Correlation between antigen expression rate and outcome. We examined the correlation between CA9 expression and 


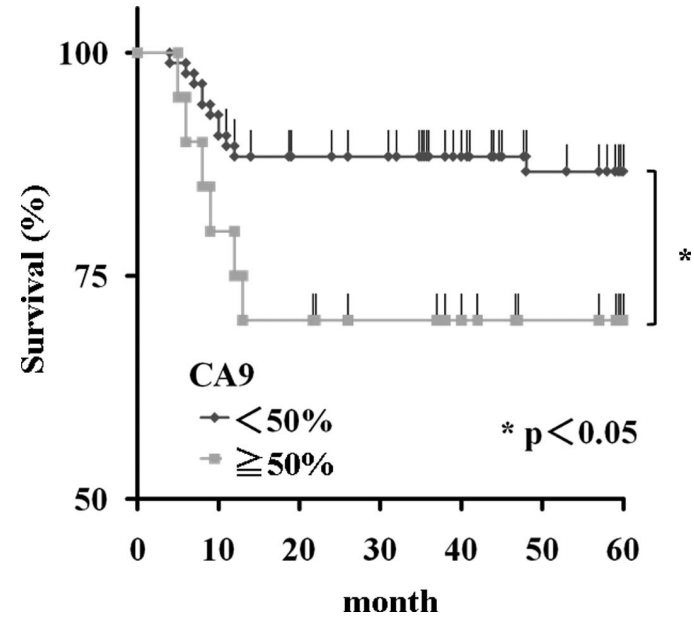

Figure 3. Correlation between CA9 and outcome. High CA9 expression (percentage of positively stained tumor cells: $\geq 50 \%$ ) was significantly related to poorer survival as illustrated by Kaplan-Meier curves.

Table II. Cancer-related antigen positive rate of oral squamous cell carcinoma.

\begin{tabular}{lcc}
\hline Markers & Positive (\%) & Expression (max/min) (\%) \\
\hline CA9 & $105(98)$ & $39(71 / 2)$ \\
GLUT-1 & $105(98)$ & $37(73 / 0)$ \\
Ki-67 & $99(92)$ & $34(90 / 4)$ \\
p53 & $84(78)$ & $34(91 / 0)$ \\
\hline
\end{tabular}

Table III. Correlations of CA9 with cancer-related antigen.

\begin{tabular}{lccc}
\hline & $\begin{array}{c}\text { CA9 }<50 \% \\
\text { expression } \\
(\mathrm{n}=87)\end{array}$ & $\begin{array}{c}\text { CA9 } \geq 50 \% \\
\text { expression } \\
(\mathrm{n}=20)\end{array}$ & $\mathrm{p}\left(\chi^{2}\right)$ \\
\hline MLUrker & & & \\
0 to $<10 \%$ & 2 & 0 & \\
$\geq 10$ to $<30 \%$ & 23 & 4 & 0.638 \\
$\geq 30 \%$ & 62 & 16 & \\
Ki-67 & & & \\
0 to $<10 \%$ & 8 & 0 & 0.079 \\
$\geq 10$ to $<30 \%$ & 32 & 4 & \\
$\geq 30 \%$ & 47 & 16 & \\
p53 & & & \\
0 to $<10 \%$ & 16 & 7 & 0.118 \\
$\geq 10 \%$ & 71 & 13 & \\
\hline
\end{tabular}

outcome, and found that subjects with a 50\% or higher positive rate had a poorer outcome compared to those with a positive rate of $<50 \%(\mathrm{P}<0.05)$ (Fig. 3). We defined a positive rate of $50 \%$ or higher as 'high expression', and $<50 \%$ as 'low expression', and further divided the subjects into two groups of well and moderate differentiated type and poorly differen-
Table IV. Correlations of Antigen expression with lymph node metastasis.

\begin{tabular}{cccc}
\hline & Metastasis (+) & Metastasis (-) & $\mathrm{p}\left(\chi^{2}\right)$ \\
\hline CA9 & & & \\
$<50 \%$ & 31 & 56 & 0.109 \\
$\geq 50 \%$ & 11 & 9 & \\
GLUT-1 & & 23 & 0.016 \\
$<30 \%$ & 6 & 42 & \\
$\geq 30 \%$ & 36 & & \\
Ki-67 & & 31 & 0.085 \\
$<30 \%$ & 13 & 34 & \\
$\geq 30 \%$ & 29 & & \\
p53 & & 10 & 0.055 \\
$<10 \%$ & 13 & 55 & \\
$\geq 10 \%$ & 29 & & \\
\hline
\end{tabular}

tiated type, based on the degree of histological differentiation. In both groups, subjects with high CA9 expression tended to have a poor outcome. Similarly, we divided the subjects into T1-3 and T4 groups according to T classification, N0 and N1-3 groups according to N classification, and Stage I-III and Stage IV groups based on disease stage, and investigated the correlation with CA9 expression. In all comparisons, groups with high CA9 expression tended to have a poorer outcome, but the difference was not significant (data not shown).

The correlation between GLUT-1, Ki-67 and p53 antigen expression and outcome was also examined, but no correlation between antigen expression and outcome was observed. In addition, no correlation was observed with CA9 antigen expression (Table III). However, when we examined the correlation between the expression of antigens and lymph node metastasis, GLUT-1 had a significant correlation with lymph node metastasis in subjects with a positive rate of $30 \%$ or higher (Table IV).

\section{Discussion}

In this study, we observed immunohistochemically the CA9, Ki-67, GLUT-1 and p53 expression in 107 subjects diagnosed with and treated for oral squamous cell carcinoma, and examined the correlation between the antigen expression and clinicopathological parameters.

As with previous reports (21-23), our analysis on the correlation between clinicopathological parameters and outcome revealed that subjects with poorly-differentiated type (histological differentiation), T4 (T classification), N1-N2 ( $\mathrm{N}$ classification) or Stage IV (disease stage at diagnosis) oral cancer had a poor outcome, and were confirmed to belong to a common patient group. However, 42 (39\%) of 107 subjects had lymph node metastasis in this study, and had a 5-year survival rate of $65 \%$. This indicates that our subjects had a better outcome compared to $30 \%$ in previous studies (24).

Expression of CA9 and GLUT-1 antigens, which was examined in this study, is regulated by hypoxia-inducible factor (HIF-1). Generally, HIF-1 $\alpha$ leads to ubiquitylation and 
degradation by the VHL tumour suppressor protein in normal oxygen conditions and accumulates without being destroyed in hypoxic conditions, by the action of prolyl hydroxylase domain containing protein (PHD) and factor-inhibiting HIF-1 (FIH-1) antigens which are expressed by acting as transcription factors $(25,26)$.

Regarding the site of CA9 antigen expression, a study, in which an antibody recognizing CA9 antigen was created, showed its expression in normal tissues of uterine mucous membrane, gastrointestinal mucous membrane including stomach and intestines, and bile duct. Our study later confirmed its expression in the basal part of skin epithelium, and CA9 antigen expression in the basal part of the oral epithelium was observed, although it was weak. Regarding its expression in cancer tissues, expression was observed in cervical cancer and renal cell carcinoma, since monoclonal antibodies were made using a cervical cancer or renal cell carcinoma cell line as the immunogen. However, recently there have been studies on the expression of CA9 in many solid tumors including bladder cancer, non-small cell lung cancer, breast cancer, esophageal cancer, stomach cancer and sarcoma.

Since, in many studies, patients with CA9 expression had a poor outcome, CA9 has been believed to be a negative prognostic factor $(8,10-16)$. On the contrary, among these solid tumors, there is one study indicating that patients with CA9 expression had a better outcome in renal cell carcinoma (9). Furthermore, CA9 expression was observed in acute myeloid leukemia (AML), a hematological malignancy, and it was reported that patients with CA9 expression had a better outcome than those without CA9 expression; thus, CA9 is considered a positive prognostic factor in AML $(17,18)$. Nonetheless, no study exists on CA9 expression in oral cancers in Japan, and its correlation with outcome is still unknown. Nor is there any case report solely on the oral region in the scientific literature. Two studies noted different positive rates of $\sim 27$ and $92 \%$ for head and neck cancers $(27,28)$. In our study, we observed CA9 expression in $98 \%$ of the subjects, and considered that $\mathrm{CA} 9$ has high prevalence in cancers in the oral region. We also examined the correlation between CA9 expression and survival rate, and found that subjects with a positive rate $\geq 50 \%$ had a significantly lower survival rate compared to those with a positive rate $<50 \%$. Subjects with poorly differentiated, Stage IV, T4 or high N factor cancer had high CA9 expression $(\geq 50 \%)$ and a tendency for a poor outcome. These findings confirm that CA9 antigen is highly expressed in oral cancer in the Japanese, and immunotherapy targeting CA9 may be possible in the future. The possibility of using CA9 as a prognostic indicator is suggested, but we believe that its accuracy should be confirmed in studies in a larger number of subjects.

GLUT-1, which regulates glucose uptake by cells and promotes glycolysis (29), is not usually expressed in the epithelium or in benign tumors, but it is expressed in several tumors including head and neck cancers (30-33). There are many studies indicating that the outcome of patients with hypoxia with head and neck cancers is poor (34-36). In the present study, GLUT-1 expression was as high as $98 \%$, but no significant correlation with the survival rate of the subjects was observed. A correlation between GLUT-1 and lymph node metastasis was reported in patients with tongue squamous cell carcinoma (37), and our study also observed a significant correlation between GLUT-1 expression and lymph node metastasis in oral cancer, demonstrating that GLUT-1 could be an indicator of lymph-node metastasis.

$\mathrm{Ki}-67$ is a nuclear protein expressed in G1, S and G2 phase $(38,39)$, and it adjunctively controls cell proliferation. Therefore, the presence of Ki-67 is considered to be a 'proliferation index' of tumors (39). In oral cancers, patients with tumors with high positivity $(92 \%)$ or lymph node metastasis had a poor outcome (40), and many studies indicated that $\mathrm{Ki}-67$ could be an important prognostic factor (41-44). Similarly, $92 \%$ of subjects showed Ki-67 expression in our study. Furthermore, Ki-67 expression was seen in $\sim 60 \%$ of tumor cells, indicating high cell proliferation of oral cancer. However, no significant correlation was observed with survival rate or CA9 expression.

p53 is a known tumor suppressor gene, and an abnormal p53 protein. Due to mutation of encoding genes, it escapes destruction by MDM-2 protein and accumulates so that it can be detected by immunostaining. p53 mutation frequency is believed to be as high as $50 \%$ in human cancers (45). One study (46) indicated low expression of p53 in oral cancer, but many other studies (5,47-49) observed expression of p53 in $50 \%$ or more tumors. In addition, there are many studies on oral cancer, especially on the correlation between p53 gene mutation, and outcome (50) and the development of oral cancer $(51,52)$. Patients with a high expression rate are treatment-resistant and their outcome with treatment is considered to be poor (53). In this study, we tried to detect mutated p53 genes including those with genetic abnormality by immunostaining, and as a result, $78 \%$ of genes in the subjects stained positive, suggesting that many oral cancers have a p53 gene mutation. However, no significant correlation was observed between p53 expression and survival rate.

In conclusion, CA9 antigen was observed in most of the oral cancer patients. Its presence was related to patients' outcome, and it is useful as a target molecule for immunotherapy against oral cancer.

\section{Acknowledgements}

We thank Mr. Marco A. De Velasco, Faculty of Medicine, Kinki University, for instruction on the image-processing method for immunostaining.

\section{References}

1. Neville BW and Day TA: Oral cancer and precancerous lesions. CA Cancer J Clin 52: 195-215, 2002

2. Tankéré F, Camproux A, Barry B, Guedon C, Depondt J and Gehanno P: Prognostic value of lymph node involvement in oral cancers: a study of 137 cases. Laryngoscope 110: 2061-2065, 2000.

3. Kowalski LP, Bagietto R, Lara JR, Santos RL, Silva JF Jr and Magrin J: Prognostic significance of the distribution of neck node metastasis from oral carcinoma. Head Neck 22: 207-214, 2000.

4. Kim SJ, Shin HJ, Jung KY, Baek SK, Shin BK, Choi J, Kim BS, Shin SW, Kim YH, Kim JS and Oosterwijk E: Prognostic value of carbonic anhydrase IX and Ki-67 expression in squamous cell carcinoma of the tongue. Jpn J Clin Oncol 37: 812-819, 2007.

5. Yuen PW, Chow V, Choy J, Lam KY, Ho WK and Wei WI: The clinicopathologic significance of p53 and p21 expression in the surgical management of lingual squamous cell carcinoma. Am J Clin Pathol 116: 240-245, 2001. 
6. Uemura H, Nakagawa Y, Yoshida K, Saga S, Yoshikawa K, Hirao Y and Oosterwijk E: MN/CA IX/G250 as a potential target for immunotherapy of renal cell carcinomas. Br J Cancer 81: 741-746, 1999.

7. Oosterwijk E, Ruiter DJ, Hoedemaeker PJ, Pauwels EK, Jonas U, Zwartendijk J and Warnaar SO: Monoclonal antibody G 250 recognizes a determinant present in renal-cell carcinoma and absent from normal kidney. Int J Cancer 38: 489-494, 1986.

8. Bui MH, Visapaa H, Seligson D, Kim H, Han KR, Huang Y, Horvath S, Stanbridge EJ, Palotie A, Figlin RA and Belldegrun AS Prognostic value of carbonic anhydrase IX and KI67 as predictors of survival for renal clear cell carcinoma. J Urol 171: 2461-2466, 2004.

9. Patard JJ, Fergelot P, Karakiewicz PI, Klatte T, Trinh QD, Rioux-Leclercq N, Said JW, Belldegrun AS and Pantuck AJ: Low CAIX expression and absence of VHL gene mutation are associated with tumor aggressiveness and poor survival of clear cell renal cell carcinoma. Int J Cancer 123: 395-400, 2008.

10. Lee S, Shin HJ, Han IO, Hong EK, Park SY, Roh JW, Shin KH, Kim TH and Kim JY: Tumor carbonic anhydrase 9 expression is associated with the presence of lymph node metastases in uterine cervical cancer. Cancer Sci 98: 329-333, 2007.

11. Klatte T, Seligson DB, Rao JY, Yu H, de Martino M, Kawaoka K, Wong SG, Belldegrun AS and Pantuck AJ: Carbonic anhydrase IX in bladder cancer: a diagnostic, prognostic, and therapeutic molecular marker. Cancer 115: 1448-1458, 2009.

12. Le QT, Chen E, Salim A, Cao H, Kong CS, Whyte R, Donington J, Cannon W, Wakelee H, Tibshirani R, Mitchell JD, Richardson D, O'Byrne KJ, Koong AC and Giaccia AJ: An evaluation of tumor oxygenation and gene expression in patients with early stage non-small cell lung cancers. Clin Cancer Res 12: 1507-1514, 2006.

13. Trastour C, Benizri E, Ettore F, Ramaioli A, Chamorey E, Pouysségur $\mathrm{J}$ and Berra E: HIF-1alpha and CA IX staining in invasive breast carcinomas: prognosis and treatment outcome. Int J Cancer 120: 1451-1458, 2007.

14. Tanaka N, Kato H, Inose T, Kimura H, Faried A, Sohda M, Nakajima M, Fukai Y, Miyazaki T, Masuda N, Fukuchi M and Kuwano H: Expression of carbonic anhydrase 9, a potential intrinsic marker of hypoxia, is associated with poor prognosis in oesophageal squamous cell carcinoma. Br J Cancer 99: $1468-1475,2008$

15. Driessen A, Landuyt W, Pastorekova S, Moons J, Goethals L, Haustermans K, Nafteux P, Penninckx F, Geboes K, Lerut T and Ectors N: Expression of carbonic anhydrase IX (CA IX) a hypoxia-related protein, rather than vascular-endothelial growth factor (VEGF), a pro-angiogenic factor, correlates with an extremely poor prognosis in esophageal and gastric adenocarcinomas. Ann Surg 243: 334-340, 2006.

16. Måseide K, Kandel RA, Bell RS, Catton CN, O'Sullivan B Wunder JS, Pintilie M, Hedley D and Hill RP: Carbonic anhydrase IX as a marker for poor prognosis in soft tissue sarcoma. Clin Cancer Res 10: 4464-4471, 2004.

17. Greiner J, Schmitt M, Li L, Giannopoulos K, Bosch K, Schmitt A, Dohner K, Schlenk RF, Pollack JR, Dohner H and Bullinger L: Expression of tumor-associated antigens in acute myeloid leukemia: Implications for specific immunotherapeutic approaches. Blood 108: 4109-4017, 2006

18. Greiner J, Ringhoffer M, Taniguchi M, Li L, Schmitt A, Shiku H, Döhner $\mathrm{H}$ and Schmitt M: mRNA expression of leukemiaassociated antigens in patients with acute myeloid leukemia for the development of specific immunotherapies. Int J Cancer 108: 704-711, 2004

19. Uemura H, Fujimoto K, Tanaka M, Yoshikawa M, Hirao Y, Uejima S, Yoshikawa $\mathrm{K}$ and Itoh $\mathrm{K}$ : A phase I trial of vaccination of CA9-derived peptides for HLA-A24-positive patients with cytokine-refractory metastatic renal cell carcinoma. Clin Cancer Res 12: 1768-1775, 2006.

20. International Union Against Cancer (2009) TNM Classification of Malignant Tumours. 7th edition, Springer-Verlag, Berlin, 2009.

21. Sessions DG, Spector GJ, Lenox J, Haughey B, Chao C and Marks J: Analysis of treatment results for oral tongue cancer Laryngoscope 112: 616-625, 2002.

22. Kantola S, Parikka M, Jokinen K, Hyrynkangs K, Soini Y, Alho OP and Salo T: Prognostic factors in tongue cancer - relative importance of demographic, clinical and histopathological factors. Br J Cancer 83: 614-619, 2000.

23. O-charoenrat P, Pillai G, Patel S, Fisher C, Archer D and Eccles S: Tumour thickness predicts cervical nodal metastases and survival in early oral tongue cancer. Oral Oncol 39: 386-390, 2003.
24. Carinci F, Stabellini G, Calvitti M, Pelucchi S, Targa L, Farina A Pezzetti F and Pastore A: CD44 as prognostic factor in oral and oropharyngeal squamous cell carcinoma. J Craniofac Surg 13: 85-89, 2002.

25. Harris AL: Hypoxia - a key regulatory factor in tumour growth. Nat Rev Cancer 2: 38-47, 2002.

26. Semenza GL: Targeting HIF-1 for cancer therapy. Nat Rev Cancer 3: 721-732, 2003.

27. Koukourakis MI, Giatromanolaki A, Sivridis E, Simopoulos K, Pastorek J, Wykoff CC, Gatter KC and Harris AL: Hypoxiaregulated carbonic anhydrase-9(CA9) relates to poor vascularization and resistance of squamous cell head and neck cancer to chemoradiotherapy. Clin Cancer Res 7: 3399-3403, 2001.

28. Ivanov S, Liao SY, Ivanova A, Danilkovitch-Miagkova A, Tarasova N, Weirich G, Merrill MJ, Proescholdt MA, Oldfield EH, Lee J, Zavada J, Waheed A, Sly W, Lerman MI and Stanbridge EJ: Expression of hypoxia-inducible cell-surface transmembrane carbonic anhydrases in human cancer. Am J Pathol 158: 905-919, 2001.

29. De Schutter H, Landuyt W, Verbeken E, Goethals L, Hermans R and Nuyts S: The prognostic value of the hypoxia markers $C A$ IX and GLUT 1 and the cytokines VEGF and IL 6 in head and neck squamous cell carcinoma treated by radiotherapy +/- chemotherapy. BMC Cancer 5: 42, 2005.

30. Airley R, Loncaster J, Davidson S, Bromley M, Roberts S, Patterson A, Hunter R, Stratford I and West C: Glucose transporter glut-1 expression correlates with tumor hypoxia and predicts metastasis-free survival in advanced carcinoma of the cervix. Clin Cancer Res 7: 928-934, 2001.

31. Kunkel M, Reichert TE, Benz P, Lehr HA, Jeong JH, Wieand S, Bartenstein P, Wagner W and Whiteside TL: Overexpression of Glut-1 and increased glucose metabolism in tumors are associated with a poor prognosis in patients with oral squamous cell carcinoma. Cancer 97: 1015-1024, 2003.

32. Mineta H, Miura K, Takebayashi S, Misawa K, Araki K, Misawa Y and Ueda Y: Prognostic value of glucose transporter 1 expression in patients with hypopharyngeal carcinoma. Anticancer Res 22: 3489-3494, 2002.

33. Mellanen P, Minn H, Grenman R and Harkonen P: Expression of glucose transporters in head-and-neck tumors. Int J Cancer 56: 622-629, 1994

34. Brizel DM, Sibley GS, Prosnitz LR, Scher RL and Dewhirst MW: Tumor hypoxia adversely affects the prognosis of carcinoma of the head and neck. Int J Radiat Oncol Biol Phys 38: 285-289, 1997.

35. Kaanders JH, Wijffels KI, Marres HA, Ljungkvist AS, Pop LA, van den Hoogen FJ, de Wilde PC, Bussink J, Raleigh JA and van der Kogel AJ: Pimonidazole binding and tumor vascularity predict for treatment outcome in head and neck cancer. Cancer Res 62: 7066-7074, 2002

36. Jonathan RA, Wijffels KI, Peeters W, de Wilde PC, Marres HA, Merkx MA, Oosterwijk E, van der Kogel AJ and Kaanders JH: The prognostic value of endogenous hypoxia-related markers for head and neck squamous cell carcinomas treated with ARCON Radiother Oncol 79: 288-289, 2006.

37. Roh JL, Cho KJ, Kwon GY, Ryu CH, Chang HW, Choi SH, Nam SY and Kim SY: The prognostic value of hypoxia markers in T2-staged oral tongue cancer. Oral Oncol 45: 63-68, 2009.

38. Schliephake H: Prognostic relevance of molecular markers of oral cancer - a review. Int J Oral Maxillofac Surg 32: 233-245, 2003.

39. Lavertu P, Adelstein DJ, Myles J and Secic M: P53 and Ki-67 as outcome predictors for advanced squamous cell cancers of the head and neck treated with chemoradiotherapy. Laryngoscope 111: 1878-1892, 2001.

40. Motta Rda R, Zettler CG, Cambruzzi E, Jotz GP and Berni RB: $\mathrm{Ki}-67$ and p53 correlation prognostic value in squamous cell carcinomas of the oral cavity and tongue. Braz J Otorhinolaryngol 75: 544-549, 2009

41. Gonzalez-Moles MA, Caballero R, Rodriguez-Archilla A, RuizAvila I and Bravo I: Prognosis value of the expression of Ki-67 for squamous cell carcinoma of the oral cavity. Acta Stomatol Belg 93: 159-165, 1996.

42. Koelbl O, Rosenwald A, Haberl M, Müller J, Reuther J and Flentje M: p53 and Ki-67 as predictive markers for radiosensitivity in squamous cell carcinoma of the oral cavity? an immunohistochemical and clinicopathologic study. Int J Radiat Oncol Biol Phys 49: 147-154, 2001.

43. Matsumoto M, Komiyama K, Okaue M, Shimoyama Y, Iwakami K, Namaki S, Tanaka H, Moro I and Sato H: Predicting tumor metastasis in patients with oral cancer by means of the proliferation marker Ki67. J Oral Sci 41: 53-56, 1999. 
44. Sittel C, Ruiz S, Volling P, Kvasnicka HM, Jungehülsing M and Eckel HE: Prognostic significance of Ki-67 (MIB1), PCNA and p53 in cancer of the oropharynx and oral cavity. Oral Oncol 35: 583-589, 1999.

45. Hollstein M, Sidransky D, Vogelstein B and Harris CC: p53 mutations in human cancers. Science 253: 49-53, 1991.

46. Unal OF, Ayhan A and Hosal AS: Prognostic value of p53 expression and histopathological parameters in squamous cell carcinoma of oral tongue. J Laryngol Otol 113: 446-450, 1999.

47. Leedy DA, Trune DR and Kronz JD: Tumor angiogenesis, the p53 antigen, and cervical metastasis in squamous cell carcinoma of the tongue. Otolaryngol Head Neck Surg 111: 417-422, 1994.

48. Xie X, Clausen OPF and De Angelis P: The prognostic value of spontaneous apoptosis, Bax, Bcl-2, and p53 in oral squamous cell carcinoma of the tongue. Cancer 86: 913-920, 1999.

49. Yao L, Iwai M and Furuta I: Correlations of bcl-2 and p53 expression with the clinicopathological features in tongue squamous cell carcinomas. Oral Oncol 35: 56-62, 1999.
50. Yamazaki Y, Chiba I, Hirai A, Sugiura C, Notani K, Kashiwazaki H, Tei K, Totsuka Y and Fukuda H: Specific p53 mutations predict poor prognosis in oral squamous cell carcinoma. Oral Oncol 39: 163-169, 2003.

51. Kusama K, Okutsu S, Takeda A, Himiya T, Kojima A, Kidokoro Y, Chu L, Iwanari S, Kudo I and Moro I: p53 gene alterations and p53 protein in oral epithelial dysplasia and squamous cell carcinoma. J Pathol 178: 415-421, 1996.

52. Girod SC, Krämer C, Knüfermann R and Krueger GR: p53 expression in the carcinogenesis in the oral mucosa. J Cell Biochem 56: 444-448, 1994.

53. Couture $C$, Raybaud-Diogène $H$, Têtu $B$, Bairati I, Murry D, Allard J and Fortin A: p53 and Ki-67 as markers of radioresistance in head and neck carcinoma. Cancer 94: 713-722, 2002. 